\title{
Normalization Method for the Detection of Low Level Chromium Contamination in the Soil of the Tisza River Floodplain (Hungary)
}

\author{
${ }^{1}$ J. PROKISCH, ${ }^{1}$ B. KOVÁCS, ${ }^{1}$ Z. GYÖRI, ${ }^{2}$ T. NÉMETH, ${ }^{3}$ L. WEST, \\ ${ }^{3}$ S. HARPER and ${ }^{3}$ D. ADRIANO \\ ${ }^{1}$ Debrecen University, Department of Food Science and Quality Assurance (Hungary), \\ ${ }^{2}$ Research Institute for Soil Science and Agricultural Chemistry (RISSAC) of the \\ Hungarian Academy of Sciences, Budapest and ${ }^{3}$ University of Georgia, Savannah \\ River Ecology Laboratory, Drawer E Aiken (U.S.)
}

In the year 2000 two significant pollution waves arrived from Romanian open mines to Hungary and drifted along the Tisza River, causing serious damages in the ecosystem of the river (ADRIANO et al., 2003). The first one, a cyanide pollution, at the end of January had instantaneous effect on the living system. The second one, heavy metal pollution in March, arised a long-term effect. The heavy metal pollution arriving with floods had two consequences. On the one hand, the increased water speed decreased the grade of sedimentation in the riverbed, and on the other hand, the flood brought contaminated water and sediment onto the floodplain. After the flood withdrew, a few centimetres of grey sediment remained in the floodplain. Subsequent floods in 2000 and 2001 resuspended and diluted the contaminated sediment on the floodplain. Lead, zinc and cadmium deposition on the floodplain were detected and proven (PÁLMAI et al., 2003), but there was no evidence of the chromium contamination earlier.

The formerly developed normalization method is a good tool for detecting chromium contamination in soil samples (PROKISCH et al., 2000), making it possible to detect 5-10-times less anthropogenic chromium contamination in soil than any other traditional evaluation method. The principle of the normalization is as follows: elements like chromium and aluminium exist naturally in the soil in a strongly bound form. In a pH range of 5-9 no leaching of these metals occurs in the soil profile and surface. The obtained inhomogeneity of these elements originates from the resuspension and migration of small soil particles. These metals remain in the solid phase and their concentration is 3-10-times higher in the $<65 \mu \mathrm{m}$ fraction than in the larger soil particles. Therefore, this redistribution results in a considerable inhomogeneity in the metal concentration of the soil. That is why a close correlation can be found between the concentration of these elements on uncontaminated areas. If the chromium and aluminium concentration measured in a sample is not on the $\mathrm{Cr}-\mathrm{Al}$ trend line, it is an indication of chromium contamination. The amount of

Correspondence to: JÓZSEF PROKISCH, Debrecen University, Centre for Agricultural Sciences, Department of Food Science and Quality Assurance, H-4032 Debrecen, Böszörményi út 138. Hungary. E-mail: jprokisch@agr.unideb.hu 
geogenic chromium concentration can be calculated from the concentration of aluminium. The differences between the measured and geogenic chromium concentration result the anthropogenic chromium concentration.

The normalization method's first step is the determination of the base line, which is a trend line between the chromium and aluminium concentration in the control soils. For this purpose a sufficient number of samples (at least 20) are required from uncontaminated soils near to the test area. In case control samples are not available, the baseline can be determined from monitoring samples of the region. In Hungary, the samples of the Soil Information and Monitoring System (TIM) (VÁRALLYAY, 1995) can be used.

The aim of the present study was to apply the normalization method for calculating the anthropogenic chromium amount in the soil of the Tisza River floodplain.

\section{Materials and Methods}

Soil samples were collected by a Hungarian-American team at two locations of eight sites on the riparian area of the Tisza River (Hungary). Six sites were in the floodplain and two were in the control area at different locations along the river. Horizontal and vertical soil sampling was carried out at each site. For the application of the normalization method only the horizontal surface samples were used.

The horizontal samples were taken within a $50 \mathrm{~m}$ radius circle in the direction of four points of the compass at $0,1,2,5,10,20$ and $50 \mathrm{~m}$ distances at each site. The surface samples were collected from the $0-15 \mathrm{~cm}$ soil layer.

Location 1 - in the Tisza River floodplain at Rakamaz - is just below the confluence of the Tisza and Bodrog Rivers. Sites 1, 2 and 4 are on the east side of the Tisza, between the current river channel (to the west) and an oxbow of the river (to the east). Site 3 - located southeast of sites 1,2, and 4 - is on a terrace associated with the Tisza River.

Location 2 - in the Tisza River floodplain at Vásárosnamény - is just below the confluence of the Tisza and Szamos Rivers. Sites 1, 2 and 3 are on the west side of the Tisza, between the current river channel (to the east) and a manmade levee to the west. Site 4 - found northwest of sites 1,2 and 3-is on a terrace associated with the Tisza River (no flooding).

The GPS coordinates and the description of the sampling sites are summarized in Table 1.

The soil samples were dried at room temperature. Before homogenization, the dried samples were crushed in a mortal. Grinders were not applied in the sample preparation, as the risk of metal contamination was to be avoided.

The "total" fractions of metals were measured from the soil samples. The socalled "total fraction" - the hot, strong acid soluble fraction - was determined by cc. $\mathrm{HNO}_{3} / \mathrm{H}_{2} \mathrm{O}_{2}$ digestion (KovÁcs et al, 2000), according to the Hungarian Standard MSz 21470-50:1998, that was traceable to the CRM BCR-141R certified reference material. 
The concentration of more than 30 elements in the obtained solutions was measured with a Perkin Elmer Optima 3300 DV ICP-OES instrument. In this study focus was laid on $\mathrm{Al}, \mathrm{Cu}, \mathrm{Cd}, \mathrm{Cr}, \mathrm{Ni}, \mathrm{Pb}, \mathrm{S}$ and $\mathrm{Zn}$, as these elements were in connection with the floodplain contamination.

Table 1

GPS coordinates and description of the sampling sites and locations

\begin{tabular}{|c|c|c|}
\hline $\begin{array}{c}\text { No. of } \\
\text { location/site }\end{array}$ & GPS codes & Description of the sampling site \\
\hline \multirow{3}{*}{$\begin{array}{l}\text { Location } 1 \\
\text { L1S1 } \\
\text { Site } 1\end{array}$} & & \\
\hline & Floodplain Rakamaz 1 & The wettest site among all. It lies in a low \\
\hline & $\begin{array}{l}48.105779^{\circ} \mathrm{N} \\
21.436207^{\circ} \mathrm{E}\end{array}$ & $\begin{array}{l}\text { point (former channel) of the floodplain. } \\
\text { Vegetation is unimproved pasture. }\end{array}$ \\
\hline L1S2 & Floodplain Rakamaz 2 & The site is closest to the river $(78 \mathrm{~m}$ from the \\
\hline Site 2 & $\begin{array}{l}48.099313^{\circ} \mathrm{N} \\
21.441713^{\circ} \mathrm{E}\end{array}$ & $\begin{array}{l}\text { channel) on a natural levee of the Tisza } \\
\text { River. Onions are grown as previous } \\
\text { crop. }\end{array}$ \\
\hline L1S3 & Control Rakamaz & Terrace of the Tisza River not subject to \\
\hline Site 3 & $\begin{array}{l}48.06674^{\circ} \mathrm{N} \\
21.477966^{\circ} \mathrm{E}\end{array}$ & $\begin{array}{l}\text { flooding. Vegetation is unimproved pas- } \\
\text { ture. }\end{array}$ \\
\hline L1S4 & Floodplain Rakamaz 3 & The site - farthest from the river within the \\
\hline Site 4 & $\begin{array}{l}48.118594^{\circ} \mathrm{N} \\
21.44037^{\circ} \mathrm{E}\end{array}$ & $\begin{array}{l}\text { floodplain - lies approx. } 150 \mathrm{~m} \text { east of } \\
\text { the oxbow. The landscape is typical of } \\
\text { most of the floodplain at this location. } \\
\text { Vegetation: unimproved pasture. }\end{array}$ \\
\hline \multirow{3}{*}{$\begin{array}{l}\text { Location } 2 \\
\text { L2S1 } \\
\text { Site } 1\end{array}$} & & \\
\hline & Floodplain Vásárosnamény 1 & The site - farthest from the river within the \\
\hline & $\begin{array}{l}48.128942^{\circ} \mathrm{N} \\
22.32739^{\circ} \mathrm{E}\end{array}$ & $\begin{array}{l}\text { floodplain - is on a slight slope from the } \\
\text { old channel to the general level of the } \\
\text { floodplain. Vegetation is unimproved } \\
\text { pasture. }\end{array}$ \\
\hline L2S2 & Floodplain Vásárosnamény 2 & The site is closer to the river than Site 1 and \\
\hline Site 2 & $\begin{array}{l}48.13106^{\circ} \mathrm{N} \\
22.33233^{\circ} \mathrm{E}\end{array}$ & $\begin{array}{l}\text { lies on the general level of the flood- } \\
\text { plain. Vegetation: planted Popular trees. }\end{array}$ \\
\hline L2S3 & Floodplain Vásárosnamény 3 & The site $-75 \mathrm{~m}$ from the Tisza River on a \\
\hline Site 3 & $\begin{array}{l}48.124927^{\circ} \mathrm{N} \\
22.335821^{\circ} \mathrm{E}\end{array}$ & $\begin{array}{l}\text { slightly higher natural levee from the } \\
\text { river -is a cropland with sunflower as } \\
\text { previous crop. }\end{array}$ \\
\hline L2S4 & Control Vásárosnamény & The site is on a terrace of the Tisza River not \\
\hline Site 4 & $\begin{array}{l}48.150714^{\circ} \mathrm{N} \\
22.287194^{\circ} \mathrm{E}\end{array}$ & $\begin{array}{l}\text { subject to flooding. No flooding for the } \\
\text { past } 170 \text { years according to the collective } \\
\text { memory of local persons and ancestors. } \\
\text { Vegetation is unimproved pasture. }\end{array}$ \\
\hline
\end{tabular}


The other sample set (country scale) originated from the soil samples of the Soil Information and Monitoring System (TIM), which is an independent subsystem of the integrated Environmental Information and Monitoring System (KIM) in Hungary. The TIM samples were taken based on physiographical-soil-ecological units. 1200 "representative" observation points all over Hungary were selected (and exactly defined by geographical coordinates using GPS): 800 points on agricultural land, 200 in forests and 200 in environmentally threatened "hot spot" regions (representing 12 different types of environmental hazards, or particularly sensitive areas (such as: degraded soils; ameliorated soils; drinking water supply areas; watersheds of important lakes and reservoirs; protected areas with particularly sensitive ecosystems; "hot spots" of industrial, agricultural, urban and transport pollution, military fields; areas affected by (surface) mining; waste (water) disposal affected spots). The soils were analyzed twice in independent laboratories, with different instruments, but following the same methods. For this study the "total" $\mathrm{Al}$ and $\mathrm{Cr}$ concentration data of uncontaminated arable fields were used.

\section{Results and Discussion}

The first step of the normalization method is the determination of the chromium-aluminium correlation and the trend line between the data in the control soils. For this reason all of the Al-Cr data obtained from the two control areas were compared to the 1200 TIM soil data. The Al-Cr concentration in the soil of the control areas (L1S3, L2S4) shows a picture of an uncontaminated soil, as was preconsidered (Fig. 1).

The $\mathrm{Cr}-\mathrm{Al}$ trend line determines the equation suitable for calculating the geogenic $\mathrm{Cr}$ concentration of the soil. For the studied region the following equation can be applied:

$$
C_{C r \text { (geogenic) }}=0.001346 * C_{A l(\text { measured })}
$$

where: $C_{C r \text { (geogenic) }}$ means the geogenic concentration of chromium, and $C_{A l(\text { measured })}$ is the measured aluminium concentration of soil (expressed as $\mathrm{mg} / \mathrm{kg}$ ).

Fig. 2 shows the correlation between $\mathrm{Cr}$ and $\mathrm{Al}$ data in the TIM and floodplain samples. It is easy to recognize that the data points for the floodplain are not on the trend line determined by the TIM samples. According the normalization method, the anthropogenic chromium concentration can be calculated as the difference of the measured and geogenic chromium concentration:

$$
C_{C r(\text { anthropogenic })}=C_{C r(\text { measured })}-C_{C r(\text { geogenic })}
$$

Fig. 3 presents the calculated anthropogenic chromium concentrations for all sampling sites. Anthropogenic chromium is not detectable on the control sites, but a significant amount (4-14 mg/kg) was found in the floodplain samples. From Fig. 4 - showing the measured total chromium concentration values - the difficulty of determining contamination only from the total chromium concentration values becomes evident. The "total" Cr concentration values measured in samples of sites 


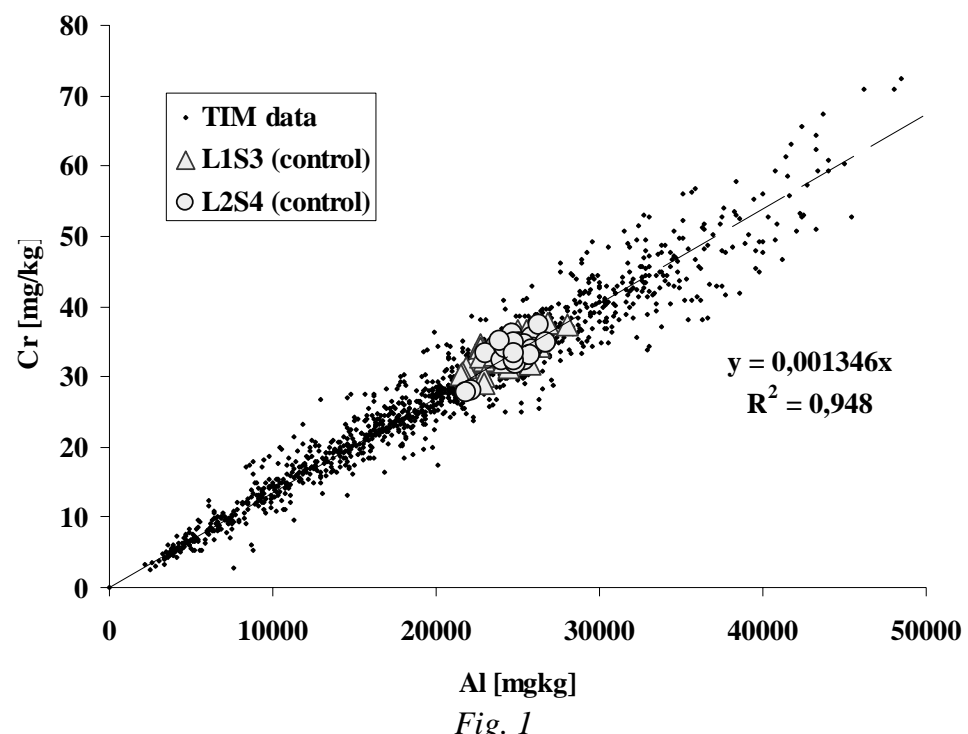

Fig. 1

Correlation between $\mathrm{Cr}$ and Al data in the TIM (Hungarian Soil Information and Monitoring System) and control sampling sites of Location 1 and 2 (L1S3, L2S4) in the Tisza River Floodplain (Hungary)

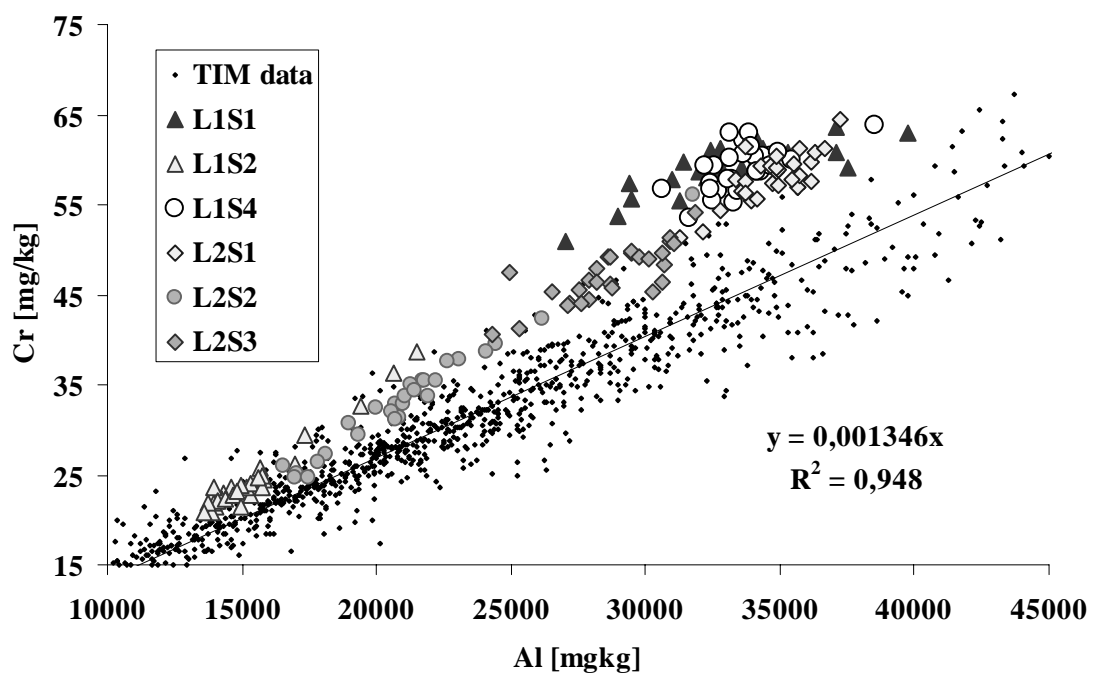

Fig. 2

Correlation between $\mathrm{Cr}$ and Al data in the TIM (Hungarian Soil Information and Monitoring System) and sampling sites of Location 1 and 2 in the Tisza River Floodplain (Hungary)

(For the description of the sampling sites: see Table 1) 
L1S2 and L2S2 are lower or not significantly higher than the control values, but these sites have an anthropogenic chromium content around $4 \mathrm{mg} / \mathrm{kg}$. This concentration means $12 \mathrm{~kg}$ anthropogenic chromium per hectare.

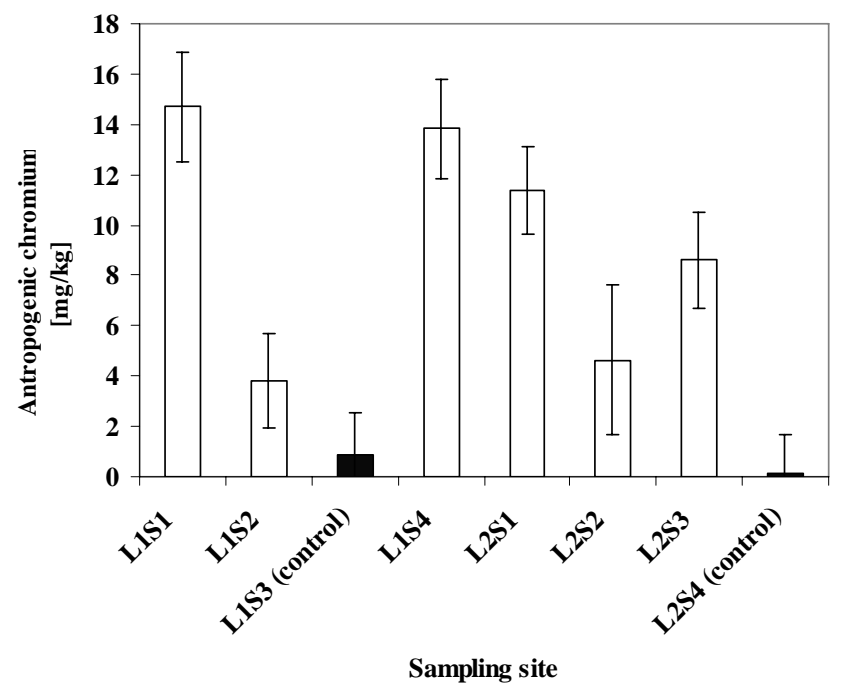

Fig. 3

Calculated anthropogenic chromium concentration for soil samples collected from the 0-15 cm layer at sampling sites in Location 1 and 2 (Tisza River Floodplain, Hungary)

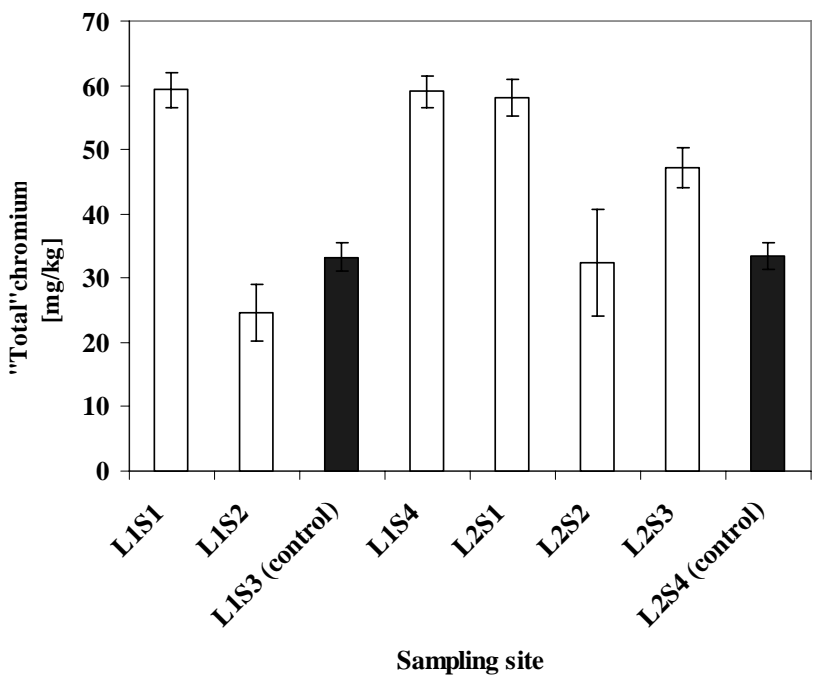

Fig. 4

"Total" chromium concentration measured in soil samples collected at sampling sites in Location 1 and 2 (Tisza River Floodplain, Hungary) 
The applied normalization method serves proof of the metal contamination on the Tisza River Floodplain. The elevated level of copper, lead and cadmium content of floodplain soils had been detected earlier. The amount of anthropogenic chromium contamination is far off the level of environmental disaster. The total chromium concentration falls below the permitted soil chromium values (B level: 75 $\mathrm{mg} / \mathrm{kg}$ ) and no toxic chromium(VI) occurs in the soil. The elevated level of chromium has no effect on the plants or on the groundwater.

The application of the normalization method has other important results: the soil chromium contamination can be detected at such an early stage in a monitoring system that gives opportunity for taking the necessary actions to identify and control the source of contamination, and to stop the progress of the environmental risk in time. The method is quite sensitive, even such amounts as $3-5 \mathrm{mg} / \mathrm{kg}$ anthropogenic chromium are detectable. The method could possibly be an important element of the evaluation procedure of soil monitoring system data and the evaluation of environmental soil test results.

\section{Summary}

A normalization method was tested for the detection of low level chromium contamination in the soil of the Tisza River Floodplain in Hungary. The soils' so-called "total" metal concentration (strong acid extractable fraction) is the basis of many environmental evaluation methods, soil tests.

In the floodplain soils cadmium, lead, zinc and copper occur in elevated concentrations, but their chromium concentration is not significantly higher than that of the control soils.

The normalization method makes it possible to calculate the anthropogenic and geogenic chromium concentration in soil. Anthropogenic chromium was not detectable on the control sites, but a significant amount $(4-14 \mathrm{mg} / \mathrm{kg}$ ) was found in the floodplain soil samples. The applied normalization method proved the low level chromium contamination in the floodplain.

The present work was supported by the Bolyai János Scholarship, and the Hungarian National Scientific Research Fund (OTKA) under grants T038450 and T042534.

Key words: chromium, normalization, floodplain soil, Tisza River

\section{References}

Adriano, D. C., NÉmeth, T. \& GyÖRI, Z. (Eds.), 2003. Natural Attenuation of Metals along the Tisza River-Floodplain-Wetlands Continuum. Licium Art, Ltd. Debrecen. 
KovÁCS, B. et al., 2000. Studies on soil sample preparation for inductively coupled plasma atomic emission spectrometry analysis. Commun. Soil Sci. Plant Anal. 31. $11-14$.

PÁLMAI, O. et al., 2003. Survey of heavy metal contamination in the flood area of the Tisza River in Hungary. In: Natural Attenuation of Metals along the Tisza RiverFloodplain-Wetlands Continuum. (Eds.: Adriano, D. C., NÉmETH, T. \& GYÖRI, Z.) 137-145. Licium Art, Ltd. Debrecen.

ProkisCH, J. et al., 2000. Yttrium normalisation: A new tool for detection of chromium contamination in soil samples. Environmental Geochemistry and Health. 22. (4) 317-323.

VÁRAllyay, Gy., 1995. Methodology: Soil Information and Monitoring System 1. (In Hungarian) Ministry of Agriculture. Budapest. 